\author{
Alexander N. Chumakov \\ Finance University under the Government of the Russian Federation, \\ 49, room 105, Leningradsky Prospekt, RU-125993 Moscow \\ chumakov@iph.ras.ru
}

\title{
Culture in the Global World and Opportunities for Dialogue
}

\begin{abstract}
Modern globalization is most brightly manifested in culture. It is confirmed by the existence of "mass culture", confronting, as a rule, national cultures. Relations between the Christian and the Islamic world, between the East and the West, whose value orientations differ significantly, are also a serious contribution to international insecurity and an obstacle to the processes of cultural globalization. Conflicts can also take place within a culture-this is known as counterculture, becoming the culture's antipode. At the same time, the history of mankind knows rare cultures having no contacts with the outside world. Therefore, dialogue of various cultures in the global world becomes a condition for their survival and the survival of the world community as a whole. Moreover, the age of globalization leaves no alternative to dialogue; otherwise, the humanity has no chance to survive.
\end{abstract}

\section{Keywords}

culture, global world, cultural globalization, dialogue, conflict, values, interdependence

Culture embraces, or, to be more precise, it literally penetrates all spheres of spiritual and material life of a society. That is why it is, in this or that way, fully involved in the process of globalization. Many culture-related problems have emerged from this fact, and they growingly acquire international or even global character. Difficulties and contradictions engendered by increasing influence and broad expansion of "mass culture", periodically emerging crises of spirituality, increasing apathy, feeling of being lost, insecurity, etc. are some of the examples. In this situation interaction, dialogue, and mutual understanding of various cultures are becoming more and more significant, although the modern world is not ready for such things. A special role is played by uneasy relations of the modern Western culture and the traditional Oriental cultures. Indigenous cultures of the developing Asian, African, Latin American cultures, relations built between the Christian world and the Islamic world, with radical difference in value orientations and socio-cultural patterns, are also a serious factor of international insecurity and confrontations to the process of globalization of culture (Global Studies Encyclopedic Dictionary, 2014: 112).

We can trace real influence of globalization on culture already in the era of the great geographic discoveries, when cultural connections and communications for the first time in human history actually became planet-wide, although in the beginning they had been fragmented and limited to contacts between sailors, traders, conquerors. Since that period the first signs have emerged if not 
of a unification, but at least of global loaning and spreading of material and cultural values as well as cultural achievements which, as a result of expansionist aspirations of the Europeans and increasing world trade, expanded throughout the world. Through this, the best scientific and technical achievements of separate countries and nations, the most convenient and useful samples of manufactured daily goods, utensils and cloths, many agricultural crops started to expand over the world more and more actively, taking root in other cultures.

It was how gun-powder and guns, mechanical clock and navigation equipment, silk and porcelain, tea and coffee, potatoes and corn, tomatoes and many other things, being initially born by local cultures, were step by step winning admission from other nations and eventually became elements not only of their cultures but of the cultural heritage of the whole world community. Along with objects of material culture, various elements of spiritual culture were granted opportunities to expand world-wide, for example, language (first of all, Spanish, Portuguese, English, French), religions (Christianity, Islam, Buddhism), whose missionaries started to penetrate previously unknown regions and corners of the world. Thus, as a result of the emergence of globalization, which had opened principally new opportunities for communication and provided the ability to spread various ideas throughout the world, these religions acquired their full universal meaning and became to be known as "world religions".

Even more opportunities emerged for broad expansion of material and spiritual values at the turn of the 19th and the 20th century, when new transportation means started to develop: railways, automobiles, aviation; the modern means of mass communication were also invented in this period: telephone, cinema, radio, TV. As a result, mutual penetration and mutual assimilation of various cultures in the 20th century, as objective and necessary consequences of globalization, have led to the formation of the universal, planetary culture. Its contours can be relatively well seen already in every country and continent, where the established way of life, traditions, and daily peculiarities coexist, based on complementarity principle, with the newest domestic appliances and mass consumption goods, sometimes manufactured somewhere in the other corner of the planet.

But cultural globalization is not limited only to using the same cell phones, radio, television, transportation means, etc. by various nations. It can also be seen in the design of cars, aviation, or home appliances being practically indistinguishable from culture to culture. Their design and production, as a rule, already have no sign of their manufacturers' national cultures and differ from their analogies only by labels with country-manufacturer on them. It is the same for products manufactured by transnational corporations, having their filiations in many countries of the world, where some factories produce completing details while assembling of the manufactured goods is done in some other place.

Although in human history one can find examples of existence of cultures being self-sufficient and practically without contact with the outside world, it would be, nevertheless, a rare example, not regularity. In fact, nearly every culture has an imprint of other cultures influencing it, mostly neighbouring cultures, but the extent may be even greater, especially with the most developed and, hence, more attractive cultures from the viewpoint of exchanging experience, results, achievements. It is particularly clear if we take loans typical nearly for all languages, having, as a rule, words of foreign origins, as 
well as parables, sayings, phrases, borrowed from other cultures. Broad expansion and transmission of ideas, inventions, scientific discoveries, religious beliefs, material and spiritual values, techniques and technologies, born by some separated culture into other countries and nations also proves cultural interdependence, typical for the entire world history.

It seems evident that interdependence plays an important role in cultural development. It has, in fact, universal character and can be realized in various forms. It can be uninterrupted when we take e.g. the development of everyday life culture and language, or interrupted as it took place in the case of the Renaissance, when material values and socio-cultural traditions of the past (the Antiquity) became visible after a significant period of oblivion.

Cultural interdependence can also be direct, in the case of loans taking place as a result of a natural evolution through choice and preservation of the most valuable and vivid elements, or indirect, when transmission of achievements is not done immediately but some time hence via additional intercessors. One of the examples is typography, which initially emerged in Germany and expanded eventually throughout the world, or with ideas and cultural values resurrected by the West European Renaissance and later adopted by other countries and nations.

It is important to mention that such loans are not always creative and taken easily; they often engender some social tensions and critical evaluation. For example, a famous Russian philosopher Ivan A. Il'in mentioned originality of Russian culture and theorized that we should not mechanistically loan spiritual culture of other nations and imitate them thoughtlessly. He wrote that

"Each nation creates what it can, based on what was given to it. But it is a bad nation that does not see what was given exactly to it and panhandles at the doors of the others. Russia has its own spiritual and historical gifts and is called to create its own spiritual culture: culture of heart, of contemplation, of freedom, and objectivity. There is no 'Western culture' obligatory for everyone, comparing with which all the rest are 'obscurantism' or 'barbarity'. The West is not our law and not our jail. Its culture is not the ideal of perfection [...]. And we have no need to pursue it and to make it our ideal. The West has its own misconceptions, illnesses, weaknesses, and dangers. Westernizing is not a salvation for us. We have our own ways and our own tasks." (Il'in, 1992: 327-328)

It should be mentioned that the Western culture has also experienced many problems and even shocks caused by intercultural antagonisms. Numerous religious wars in Europe or stubborn French defence of the priority and purity of their language under the pressure of English, which has already replaced French internationally as a language of diplomacy, evidently confirm the correctness of our statements.

Moreover, the history of nations on other continents tells the same. In particular, the hard experience of establishing cooperation between the European countries and the countries of the Orient can be and should be a good basis for discussing a principle possibility of mutual influence and interaction of various cultures, as well as for finding principal and irremovable differences between them. Underestimating this may engender, in some circumstances, misunderstandings, tensions, or even conflict situations. A well-known incident with a British ambassador in China Lord McCartney, who in 1793 was refused accreditation at the court of Jiànlóng, can serve as a good example. The Emperor of China wrote in this regard in his letter handed to a British king George III:

"We have everything and your ambassador can confirm it. I don't pay much attention to exotic or primitive things and we don't need the goods of your country." (Toynbee, 1991: 83) 
Less than 200 years have passed since these lines had been written, and now China is not just open for the outside world but has literally flooded the whole world with its goods. These facts confirm irrepressible force and communicative direction of modern globalization forcing even the most closed societies to open in the end. The idea is that China itself is not the point, but the objective of globalization processes. One can study the practice of other countries, such as Japan, which has completed nearly the same way from full self-isolation to aggressive expansionist policy in the 20th century. Japanese military policy has finally failed but it became really effective in the sphere of manufacturing, especially in electronics, high technologies and motor-building. Contrasting experience in modern history, for instance, North Korea and Cuba, is also of great interest because it clearly demonstrates that poverty and backwardness in socioeconomic development are, in fact, inevitable if today a country chooses the way of self-isolation from the rest of the world.

Nevertheless, the problem of intercultural interaction, and even confrontation and antagonism, of various cultural traditions and systems has not become less important. Moreover, it acquires new depth and new forms, intensively moving to the foreground the necessity for dialogue and cooperation based on mutual understanding and mutual respect of all the numerous cultures representing modern humankind. It is just to mention that not only in the East but also in the West it is more and more understood that the Eurocentric vision of the world order and world events, being so wide-spread in the previous centuries, has evidently withered away in the context of the growing globalization process. One of the most well-known scholars of the problems of contemporary world, the American political scientist Samuel Huntington also admits, that

"[...] the West has conquered the world not due to superiority of its ideas, values or religion (into which some members of the other civilizations were converted), but due to superiority in using organized violence. It is often forgotten in the West; it is always remembered in the nonWestern civilizations." (Huntington, 1999: 510)

Our position is confirmed by another, different vision of the Western culture, its values, and generally of the capabilities of dialogue and cooperation between significantly different cultural, political, and religious systems. Now we talk about the position of the Islamic East, represented in the book by the former president of Iran Mohammad Khatami, Islam, Dialogue and Civil Society. Here he writes:

"By rejecting the West, we want to liberate ourselves from its political, spiritual, cultural and economic domination, for, being Muslims, we initially differ from people of the West in terms of our worldview, our values." (Khatami, 2001: 217)

The Western civilization, Khatami writes, is based on the ideas of freedom and emancipation. He suggests that generally it has had positive impact on the European culture after its liberation from many superstitions and prejudices that had enslaved thinking, politics, and the society. But the West, he mentions, has generally wrong vision of freedom, humankind, and the world as a whole. Khatami adds:

"We really disagree with the West on the issue of freedom. We don't think that the definition of freedom, accepted by the West, is perfect. Western vision of freedom cannot guarantee happiness for the humankind. Historically constructed organization of life and thinking of the West is so concentrated on it itself that it is unable to see disasters caused by its wrong vision of the humankind and freedom." (Khatami, 2001: 218-219) 
The above-brought examples seem enough to conclude: relations of dialogue and conflict between various cultures are their natural attributes and even needful forms of their existence, like e.g. political struggle and political agreements being inseparable part of any political system. The nature of this interconnection is based on natural laws, one of which - unity and struggle of the opposites - for a long time has been a subject of philosophical speculations and can be applied to the sphere of culture, woven of the opposites and contradictions.

On the one hand, cultures cannot do without interaction, without mutual positive influence. It is so because communication, existing for ages between nations in the sphere of trade and commercial exchange, has always contributed to broad expansion not only of material values but also spiritual, aesthetic norms, partly being by this or that way loaned and assimilated by other cultures, and eventually becoming their elements. Political relations also cannot be effective and cannot even be established without dialogue and mutual understanding of the contracting parties, independently of their culture. From this viewpoint, the contemporary world situation deserves special attention. It is characterized by increasing globalization which alters the very idea of dialogue and the forms of its existence.

Globalization has not just suddenly sharpened contradictions accompanying the humankind for ages and millennia. It has brought them qualitatively and quantitatively to the new level, having transformed formerly regional problems into global ones and, at the same time, resulting in principally new, previously non-existent problems and disagreements. The sharpness of modern contradictions is mainly caused by the clash of two trends - the integration process, including the area of culture, and the aspiration of national, local cultures to defend their originality and independence. One can conclude that any "oppression", imposition, or coercion in intercultural interaction cannot be successful.

In this regard, dialogue - as a form of relations between individuals, communities, and groups of people, between nations, states and, more broadly, between cultures (for example, the West and the East, Islam and Christianity) - becomes not only an objective demand, but an absolute necessity. M. V. Ratz, a professor from Jerusalem, speaks about it, discussing the issue of tolerance and dialogue in the modern world:

"If we still keep our optimism and believe in the force of reason, we should not only count on tolerance, but to develop our dialogue ability. Tolerance is necessary, but not sufficient. Dialogue is not a panacea either, but, unlike tolerance, at least it provides a prospect for development." (Ratz, 2004: 30)

Nowadays, when there is a significant number of countries having nuclear, chemical, and biological weapons in the world, dialogue between these countries (it always takes place in a specific cultural, political, and historical context) is the only possible way of resolving inevitable contradictions. This is needed in order to avoid catastrophic consequences for both the conflicting parties and for the humankind as a whole, because increasing intensity of globalization processes just leaves no other choice for people.

Apart from this, globalization not only expands opportunities for making a policy of dialogue, but creates new conditions, engendering phenomena that present obstacles for it. For example, every dialogue implies clearly defined goal, distinctness, and clarity of the included parties' positions, and, consequently, the presence of personal element and rationally based conduct of those who participate in this dialogue. Such qualities are possessed by sepa- 
rate persons and responsible representatives, public and state figures, having relevant authorities for negotiations in question. At the same time, unorganized groups of people, spontaneously formed mobs, and, more than that, a mass of people being the basis of the "mass society" is not sensitive to dialogue. Conditions providing existence and reproduction of "mass culture" do not also contribute to dialogue. A respected scholar of this problem, José Ortega y Gasset, wrote, that

"[...] dialogue is the highest form of communication allowing discussing the fundamentals of nowadays. But for a man of the mass to accept discussion is to fail inevitably, and he instinctively refuses to accept this highest objective authority." (Ortega y Gasset, 1989: 14)

Thus, globalization, by creating conditions for the emergence and expansion of the mass culture and demanding, at the same time, increasing and more effective dialogue, produces a highly contradictory situation. In other words, it plays a double role - on the one hand, it contributes to the development of dialogue, on the other hand, creates additional obstacles to it, the most of which directly affect the sphere of culture.

In fact, cultural disagreements and contradictions mostly explain the fact that the modern globalizing world, with transcending borders and eliminating obstacles to communication and human contacts, is still characterized by political, economic, spiritual, and even material walls and barriers. Here we could point not only to trade and economic wars permanently waged between, for example, Japan, the United States, and the European Union, or to political and diplomatic conflicts emerging periodically with various pretexts, but also to real walls still constructed in the modern world. For example, the Berlin Wall, which was a result of ideological disagreements and a symbol of contradiction of different cultural and political systems, was in the course of time destroyed, but it has not become the last example reminding that in the global world it is impossible to be separated either by real or virtual walls from "inconvenient" or "incompliant" neighbours, whom, as we know, one cannot choose. In the 21 st century, Israel, after a desperate constant war against terrorism, starts to build a wall to be separated from the Palestinian territories, while in the United States, due to the increasing flow of illegal immigrants, the issue of building a wall at the Mexican border is seriously discussed.

Pointing to these rudiments of human antagonism, we should also emphasize that some obstacles to building constructive and effective dialogue between people can be found in the contradictory nature of human beings themselves. A. A. Guseinov says:

"People value external form higher than internal essence; they value more that which differentiates them from others than what unites with them. That is why I think that dialogue of cultures has limited abilities." (Guseinov, 1999: 20)

Having in mind the above-mentioned circumstances, one can conclude that the dialogue between cultures cannot do without contradictions and even conflicts. And it is so both because of the multi-faceted human essence, and of the contradictory nature of culture itself. Culture is a differentiated, dynamic phenomenon, and any given culture has inevitable originality and difference from other cultures with which it establishes contacts. And these conflicts should not necessarily be evident, have open or even exacerbated form; they are sometimes of a hidden, obscure, or covered nature, appearing in the foreground only under certain circumstances. Sometimes they remain unactualized, losing in the course of time any ground for open manifestation. 
One can bring limitless number of examples of such conflicts, but war has always been the brightest expression of intercultural confrontations. As a rule, it is an external manifestation, an apogee of contradictions, which were ripening for a long period covertly. When they become evident, they take various forms of violent struggle. Internal or hidden conflicts inevitably accompany all cultures, as well as intercultural relations (sometimes they are perceived as interethnic), and they can be externally displayed through, for example, an ironical attitude to some ethnic way of life, ignoring its material and spiritual achievements, rejecting specific traditions and norms, becoming subject to jokes and mockery, etc.

Counterculture is one of the forms of a conflict manifestation inside a culture itself, which by this or that way becomes its antipode. Counterculture emerges, as a rule, on the basis of unresolved problems, accumulated contradictions, and confrontation of various interests; it is fed by them and mostly becomes opposed to the accepted norms, established "traditional" values, principles, ideals, calling for their new understanding, rethinking on other grounds. Such movements directed towards modernization of cultures existed nearly at every historical period, and they always generated new ideals, providing impulse to changing previous ideals. They thus performed, on the one hand, an important function of renovating previous forms, relics of the past, overcoming everything what was stagnant, dogmatic, and non-viable. On the other hand, they performed a destructive function becoming extremist and violent. Counterculture becomes particularly strong in a period of social crises, accompanied by revolutions - social convulsions, affecting the deepest foundations of culture, bringing upon a deep crisis.

Countercultural examples can be found already in the ancient times, and the brightest of them is, we think, the Greek philosophical school of cynics, rejecting the accepted moral norms and living principles and challenging the society by extravagant behaviour of its representatives. The very term 'cynics' (meaning 'dogs' in Greek), used by them with pride, represents their lifestyle and behaviour, based on neglecting traditional norms of living, denying laws of polices and a wish to live in accordance with natural laws, rejecting fatherland and proclaiming themselves 'cosmopolitans'. The essence of this counterculture is reflected brightly in many stories and fables about a legendary representative of cynical philosophy Diogenes of Sinope, who demonstratively lived in a barrel, having limited his demands to the minimum, thus expressing his aspiration to finding natural freedom and full independence from external events.

Recently, some wave-like movements of the 20th century are definitely countercultural, such as hippies, Hóng Wèi Bīng, New Left, as well as demonstrations of sexual minorities, various reformist or schismatic movements emerging periodically in this or that church or religious confession; in particular, Protestantism, Baptism, duhobory, Wahhabism, Krishnaism and many others used to be countercultural phenomena. Counterculture is also represented by various protest movements directed against forms of violence, exploitation, unjust relations in the sphere of economy, politics, social relations, etc. These are political parties and social movements of the "Greens", international organizations like Greenpeace and "antiglobalists", widely known nowadays. Actually, they are not against globalization as such - they protest against unjust relations, becoming more visible and acute in the modern world under the influence of the objective globalization process (Chumakov, 2005).

In this regard one curious phenomenon deserves attention. Since the moment of "discovering" the global problems of modernity in the last third of the 
20th century and the active search for the ways to overcome them, there have been, in fact, no principal disagreements between parties interested in their resolution. Actually, all countries and peoples of the world were interested in it, because global problems represent an equal threat for all people on the planet. Now, when we talk about globalization, no similar opinion can be heard. It is not the point that here one can see in the most evident form the true role and "personal contribution" of this or that country to the emergence and enhancement of specific global problems. The point is that, having found the main causes of their emergence, we necessarily came to another question: who and how should make efforts for resolving these problems. And this tackles interests of some certain countries, or organizations, industrial groups they represent.

All of this means only that in the foreseeable future we should expect only increasing confrontation and struggle between various interacting actors in the contemporary global world. This suggestion is confirmed by the fact that "every world actor now has no permanent and 'faithful' allies, they only have constant national interests, not coinciding with or contradicting interests of the others" (Tancher, Kazakov, 2005: 65). In fact, M. V. Ratz means the same, writing that

"It is of special importance to find proper names for everything. We should admit that peaceful coexistence so far remains an unachievable ideal. Rationally thinking people long ago understood that it was not achievable practically. It is more difficult to agree that it is not grounded even in minds. It seems that it cannot be grounded theoretically [...].” (Ratz, 2004: 30)

In other words, universal consent and mutual understanding are so far away that they seem to be principally impossible.

But the history of many different social systems demonstrates that isolated cultures, as well as those who oppressed multiculturalism, are prone to stagnation, poverty, monotony, decline of creative activity of the significant part of the population. In the end they inevitably degrade. In human history we can find many examples proving that the most intense social, economic, and cultural development took place in cases of promoting cultural diversity and where trade ways crossed due to favourable geographic conditions, expanding transnational cultural ties. There is no doubt that contacts, interactions, mutual influence and exchange between various local and national cultures were, for a long time, one of the reasons of active development, prosperity, and progress of cultures at terrestrial cross-roads like the Middle East, or at the sea shore, like in the Mediterranean, or at the coast of the Indian Ocean.

Evaluating the current situation, one should stress that the role and meaning of dialogue of cultures have grown even more. Universal interdependence in the global world is so high that any attempt to resolve international conflicts and social problems by violence (physical, spiritual, psychological, ideological, economic, etc.) or even "pressure", on behalf of, for example, the "directing culture" should be excluded. I. V. Bestuzhev-Lada is right when he writes:

"Sword is the worst tool for resolving the global problems of modernity." (Bestuzhev-Lada, 1996: 80)

The only result guaranteed by such methods is exacerbation of the past conflicts and emergence of the new ones, often more severe. The reason for this is the essence of culture that cannot be changed quickly and, especially, by force. 
"In real life neither religious decrees, nor fruitless dreaming can prevent the advancement of Western culture. But neither memorandums, nor doctrines can also log the tradition off." (Khatami, 2001: 162)

And this seems a serious argument in favour of multiculturalism and dialogue of various cultures, the only alternative to which is, having in mind nuclear potential of a significant number of independent states, self-destruction of the whole humankind.

There are many historical examples of resolving disputes through dialogue, but so far we can see no trend towards such relations between people and various communities becoming deeply rooted and durable. Acute conflicts emerging here and there to be resolved by force, threats, and various forms of pressure demonstrate that attempts to dialogue are still more episodic than consistent.

For a stable dialogue and, moreover, for it to become the main method of human communication, we need to replace the power of force with the power of spirit. It is basically impossible without a certain level of development of spiritual and material culture. The past epochs, for fully objective reasons, could not provide such level of cultural development, an also "paid" severe, but not mortal, price for relatively low level of this development. The age of globalization leaves no alternative to dialogue; otherwise, the humanity has no chance to survive.

\section{References}

Bestuzhev-Lada, I. V. (1996): V preddverii Strashnogo Suda ili Izbezhim li predrechennogo $v$ Apokalipsise? Moscow: FON.

Chumakov, A. N. (2005): Globalizatziya: Kontury tzelostnogo mira. Moscow: Prospekt.

Global Studies Encyclopedic Dictionary (2014), ed. by A. N. Chumakov, I. I. Mazour, and W. C. Gay, with a foreword by M. Gorbachev. Amsterdam, New York: Rodopi.

Guseinov, A. A. (1999): “Globalnyi etos kak problema”, in: Etos globalnogo mira, ed. by G. Shakhnazarov and V. Tolstykh. Moscow: Vostochnaya literatura.

Huntington, S. (1999): “Stolknovenie tzivilizatzii?”, in: Sravnitelnoe izuchenie tzivilizatzii, ed. by B. S. Erasov. Moscow: Aspekt Press.

Il'in, I. A. (1992): Nashi zadachi. Moscow: Rarog.

Khatami, M. (2001): Islam, dialog i grazhdanskoe obshchestvo. Moscow: ROSSPEN.

Ortega y Gasset, J. (1989): "Vosstanie mass", Voprosy filosofii, No. 3/1989.

Ratz, M. V. (2004): “Dialog v sovremennom mire”, Voprosy filosofii, No. 10/2004.

Tancher, V. V.; Kazakov, V. S. (2005): "Problema deinstitutzionalizatzii sotzialnykh konfliktov v kontekste globalizatzii”, in: Sotzhialnye konflikty $v$ kontekste protzessov globalizatzii i regionalizatzii. Moscow: Lenand.

Toynbee, A. G. (1991): Postizhenie istorii. Moscow: Progress. 


\title{
Alexander N. Chumakov
}

\section{Kultura u globalnom svijetu i mogućnosti za dijalog}

\begin{abstract}
Sažetak
Moderna se globalizacija najblistavije manifestira u kulturi. To potvrđuje postojanje »masovne kulture« koja, u pravilu, konfrontira nacionalne kulture. Odnosi između kršćanskog i islamskog svijeta, između Istoka i Zapada, čije se vrijednosne orijentacije značajno razlikuju, također su ozbiljan doprinos međunarodnoj nesigurnosti te zapreka procesima kulturne globalizacije. Konflikti se mogu odvijati i unutar neke kulture, što je poznato kao kontrakultura, odnosno antipod određene kulture. Istodobno, ljudska povijest poznaje rijetke kulture koje nemaju kontakta s izvanjskim svijetom. Prema tome, dijalog različitih kultura u globalnom svijetu postaje uvjet za njihovo preživljavanje i preživljavanje svjetske zajednice kao cjeline. Štoviše, doba globalizacije dovelo nas je do toga da dijalog nema alternative jer inače ljudski rod nema šanse da preživi.
\end{abstract}

\section{Ključne riječi}

kultura, globalni svijet, kulturna globalizacija, dijalog, konflikt, vrijednosti, međuovisnost

\section{Alexander N. Chumakov}

\section{Kultur in der globalen Welt und die Möglichkeiten für den Dialog}

\section{Zusammenfassung}

Die moderne Globalisierung zeichnet sich am klarsten in der Kultur ab. Dies belegt das Vorhandensein einer „Massenkultur“, die in der Regel nationale Kulturen konfrontiert. Die Beziehungen zwischen der christlichen und der islamischen Welt, zwischen Ost und West, deren Wertorientierungen signifikant voneinander abweichen, sind gleichfalls ein ernsthafter Beitrag zur internationalen Unsicherheit und ein Hindernis für die Prozesse der kulturellen Globalisierung. Konflikte können innerhalb einer Kultur stattfinden, was als Gegenkultur bekannt ist, die zum Antipoden dieser Kultur wird. Gleichzeitig kennt die menschliche Geschichte seltene Kulturen, die keine Kontakte mit der Außenwelt haben. Daher wird der Dialog zwischen diversen Kulturen in der globalen Welt zur Voraussetzung ihres Fortbestandes sowie des Fortbestandes der Weltgemeinschaft als Ganzes. Zudem hat das Zeitalter der Globalisierung den Dialog alternativlos gemacht, anderenfalls hat die Menschheit keine Chance zum Überleben.

\section{Schlüsselwörter}

Kultur, globale Welt, kulturelle Globalisierung, Dialog, Konflikt, Werte, Interdependenz

\section{Alexander N. Chumakov}

\section{La culture dans le monde globalisé et les possibilités de dialogue}

\begin{abstract}
Résumé
La mondialisation moderne se manifeste le plus vivement dans la culture. L'existence de "la culture de masse » le confirme, qui, en règle générale, confronte les cultures nationales. Les relations entre le monde chrétien et islamique, entre l'Orient et l'Occident, deux mondes dont les valeurs non seulement diffèrent significativement, mais contribue également au sentiment d'insécurité de manière importante, constituent un obstacle pour la mondialisation culturelle. Des conflits peuvent apparaître à l'intérieur d'une culture donnée et se manifester comme contre-culture en se plaçant aux antipodes de la culture. En même temps, l'histoire humaine n'a connu que très peu de culture qui n'entretiennent aucun contact avec le monde extérieur. A partir de là, le dialogue des diverses cultures dans le monde mondialisé est une condition pour leur survie et pour la survie la de la communauté mondiale en tant que tout. De plus, l'âge de la mondialisation nous a conduit à ne pas laisser d'alternatives au dialogue, car dans le cas contraire, le genre humain n'a aucune chance de survie.
\end{abstract}

\section{Mots-clés}

culture, monde globale, mondialisation culturelle, dialogue, conflit, valeurs, inter-dépendance 